\title{
Study Solar Energy Usage and Evaluation Activities around Bahir Dar, Ethiopia
}

\author{
ADDISU WORKU BEZABIH ( $\square$ addisu2116@gmail.com ) \\ technology
}

\section{Research Article}

Keywords: PVsyst software, social benefits, dissemination, tilts angle and azimuth angle, solar photovoltaic system, Bahir Dar

Posted Date: June 29th, 2021

DOI: https://doi.org/10.21203/rs.3.rs-665802/v1

License: (a) (i) This work is licensed under a Creative Commons Attribution 4.0 International License. Read Full License 


\section{Abstract}

Although solar energy is abundant, accessible, affordable, and ecologically and environmentally friendly, in rural Ethiopia, the majority of Households are still using pollutant kerosene for lighting. The researcher assess factors that influence dissemination activities, like solar PV installation practices, house and institutional system distribution strategies, system failures, and their causes. Additionally, The researcher analyzed the impact of PV orientation, comparing the simulation results currently performed by the PVsyst software with different angles observed during the sphere survey. This made it possible to influence the dissemination activity factors and, therefore, the best orientation. The study also assessed how access to alter, maintenance, lack of public awareness building, institutional problems, tariffs, and lack of a market could affect PV system access and large-scale distribution. To distribute a sufficient amount of solar PV across the country, this study recommends that consideration of distribution impact factors be considered in the most negligible levels to realize maximum results. The PV system could be a tilt at angles of $16^{0}$ and $0^{0}$ azimuths; supported by this method, the PV system can collect a mean of $5.36 \mathrm{~kW} / \mathrm{m}^{2}$ daily, which implies $1929.6 \mathrm{~kW} / \mathrm{m}^{2} /$ year. This was the vision that the researcher wish to possess a sustainable supply of energy within the country and reduce emissions from biomass.

Thus, adapting standard design practices of mathematical formulas, experimental and PVsyst methods through numerical simulation is critical to identifying ways to enhance the efficiency and reliability of stand-alone PV power systems for further practicality within the region.

\section{Introduction}

Solar Photovoltaic is one of the fastest-growing renewable energy technologies and will probably play a severe role in global electricity generation within the future $[12,17]$. Ethiopia's energy demand is overgrowing; this is often mainly thanks to an increase, high economic activity, and social life changes, which implies enormous electricity generation, distributed to any or all households and industries. Most Ethiopians board rural areas and have little or no access to electricity [40]. Electricity for those that have access comes from renewable energy. But most of the agricultural community's energy resources and even the energy needs of the suburban population are supplied by biomass, which traditionally serves the farming community as fuel preparation, heating, and mains lighting [3]. Ethiopia introduced solar electricity within the mid-1980s. At the time of GTP-1 (2011), over 3 million solar photovoltaic systems were planned to be distributed by the top of 2015 [18]. However, the target has not yet been achieved through the efforts of the agricultural Electrification Fund, private solar companies, NGOs, and, therefore, the aid mission.

Solar photovoltaic energy is renewable, healthy, and environmentally sustainable, with numerous benefits for women's health, children's education, jobs, and income generation. PV was not used on a large scale for system maintenance due to high costs, unreliable technical efficiency, and a lack of qualified staff [36]. It's also been shown that poor technical performance is usually the result of improper selection of PV systems and isn't correctly maintained [6,30]. This study explores the prevailing social and technical challenges in deploying a small-scale PV system around Bahir Dar. Accordingly, this study provides important lessons regarding its distribution, installation, and access to and use of the system component. The significant common health effects related to biomass preparation are eye and respiratory problems.

Increased household energy demand has resulted in extensive deforestation on the town's outskirts. As a result, there are severe shortages of fuelwood supplies, resulting in an energy crisis. This could significantly negatively affect the household's health, climate, and economic growth, impeding their attempts to improve their living conditions[26]. Therefore, for the bulk of urban households, meeting the energy requirement sustainably still are a severe challenge.

There is the initial opportunity cost of buying photovoltaic, charge controller, transportation of materials, labor charge, expertise charge, operation and maintenance fee, etc. in keeping with Jack T Chow, (2010) [9], Both the government and international organizations are promoting SHS as a viable and cost-effective option for essential electrification of rural households (Neuwenhout, 2002) [33]. Sukatani in Indonesia (Surya, 1992) [29] is one of the popular SHS pilot projects that has earned widespread attention. Solar home systems have steadily gained acceptance as a viable alternative for rural

Page $2 / 13$ 
electrification due to these success stories. The majority of Ethiopians live in rural areas where modern energy resources are scarce. With the support of NGOs and the private sector, the agricultural electrification fund was able to gain access to lighting. The Ethiopian government founded the Agricultural Electrification Fund as a permanent financial source through a proclamation (No.317/ 2003) [34]. To provide loans and technical assistance for rural electrification projects allocated by private operators, cooperatives, and native commonalities, focusing on renewable energy projects.

The government's budget, loans and grants from other countries, loans and grants from international financial agencies, grants from non-governmental organizations, and income from other sources are all sources of the fund. (EREPDC 2010) [35] (Source: EREPDC 2010). The most critical challenge is that most rural areas rely on cheap kerosene lamps for lighting, firewood and coal, and kitchen needs. As for installation problems, it was noted that some installations appear to be too high at an angle of inclination and face the incorrect panel. In contrast, others are located within the shade. At the same time, several users complain about the shortage of frequent maintenance [5]. While the renewed national energy policy's most goal is to push the expansion and popularization of small-scale renewable energy technologies and grid electricity, there's also attention on improving ready-made stoves for rural household use $[15,39]$. With this structure in mind, Ethiopia aspires to become a renewable energy hub by 2025 , with the energy sector playing a critical role in the country's socio-economic growth and transformation by delivering safe, dependable, accessible, high-quality energy services in an environmentally friendly manner to all sectors [36]. Mainly, it requires technical standards to facilitate the further development of the small-scale solar technology market.

The rate of electricity consumption in rural Ethiopia is far under urban coverage. This is often mainly because the agricultural population living in isolated villages is connected to the centralized electricity network [10,21, and 22]. Photovoltaic system installations have seen rapid growth around the world. However, to achieve parity with electricity supply, most PV markets would need government assistance. Several essential success factors in rural electrification must be considered for such calls long-term growth, dominated mainly by small-network PV solutions. Around the world, evaluations of the operation and reliability of effective models of solar PV systems in Ethiopia have been observed: good system design, installer and end-user training, financing, service, institutional collaboration, and so on.

The primary purpose is to check solar power Orientation and evaluation activity of the spread of solar photovoltaic technologies around Bahir Dar. Specific objectives are to assess the challenges of distribution and installation, model the solar PV orientation around the districts of Bahir Dar, optimize energy production throughout the year, and get free and environmentally friendly electricity with green gas.

\section{Methodology}

The methodology followed within the study consists of Site identification, Data collection, and Survey, additionally as data analysis.

\subsection{Location of the study area}

The study area around Bahir Dar is found within the northwest part, Amhara Regional State, Ethiopia, at 2070m. The geographical coordinates around Bahir Dar lie between the $11.6^{0} \mathrm{~N}$ latitudes and $39.5^{\circ} \mathrm{E}$ longitudes. Together, these two geographical conditions provided the most straightforward sites for photovoltaic technology development within the study area and located as shown in (Fig. 1).

\subsection{Description of the data}

The study had used both primary and secondary data. The first data were collected and observed from field surveys. In contrast, secondary data for the research were acquired from the web, reports, books, newspapers, government institutions, and other documents. The collected data were analyzed due to a descriptive survey, theoretical, experimental models, analysis of PVsyst software. The study uses meteorological data obtained from the Ethiopian and NASA National Weather Service to 
assess solar power potential. Data analysis and interpretation are made in keeping with HOMER (Hybrid Optimization Model for Electrical Renewable) software [20].

Several aspects have to be considered and evaluated about mixing PV cells into an of doors building envelope. These include location restriction, inclination and orientation, shading, partial shading, temperature effects, and so on. The idea for access to training solar resources because Ethiopia is found near the equator, solar resources' potential is critical, and the annual average daily radiation reaches $5.2 \mathrm{kWh} / \mathrm{m}^{2}$ [30]. HOMER is employed for optimization and sensitivity analysis of various possible hybrid systems [13]. This can be because of the component's likely failure and, therefore, the availability of the mandatory spare parts and, therefore, the short battery lifetime of about four years. However, the proliferation of small solar systems is understood to bring several benefits to rural communities. Advantages include the villagers' chance to own evening training, movable charging services, access to information through the possible use of radio, television, and mobile applications [16]. This study examines the character of the PV diffusion process to see the factors influencing its uptake. Similarly, it also wants to find out issues that may optimize its benefits through technical evaluation, likewise as compared to the experience of other countries in local practice.

The potential of solar power studies indicates that in Ethiopia as a full, the typical annual radiation reaching the planet is $5.26 \mathrm{kWh} / \mathrm{m} 2$ [2]. The house system (SHS), which is distributed in Bahir Dar, falls into two main categories, namely, electrical energy (AC) (which has an inverter for DC to AC conversion) and electrical energy (DC) sort of supply systems [28]. One diagram of both methods is given in (Figs. 2 and 3). These systems were distributed in rural areas where mains electricity is unavailable.

As shown in (Fig. 2), the DC system has no inverter; it only features a crystal module whose complete module features amounting structure and adjustment, an influence controller, and electric battery gel with a well-ventilated box. The DC circuit is installed between the PV module, the charging controller, and the electronic devices. On the other hand, (Fig. 3) of the AC system may be a vital component of the crystal module with complete module mounting structure and tilt adjustment, gel battery with well-ventilated box, charge controller, clean wave inverters, DC LED lamp holder, and on. Switch off, various electrical fuse sizes, dc to dc voltage converter, from $12 \mathrm{~V} \mathrm{DC}$, within the setting, use 3, 4.5, 6, 7.5 and $9 \mathrm{~V} \mathrm{DC}$, AC socket stool, DC mobile charger and socket with different pin plug [37].

\section{Results And Discussion}

\subsection{Solar PV system around Bahir Dar}

In Ethiopia, currently, small-scale solar technologies are mainly involved within the distribution of solar home systems, mainly in creating, informing, and providing technical assistance to consumers (and especially women groups that play a vital role at the household level), developers, business and financial intermediaries (micro-finance institutions).

Stakeholders emphasize the critical role that the Ethiopian Customs Bureau, importers, distributors, and retailers must play together to ensure that substandard products reach consumers and strengthen market integrity [4]. Lack of awareness is exacerbated in some rural communities by the shortage of TVs and radio stations inaccessible to those advertising channels. Public awareness campaigns must be carefully designed and targeted to beat these barriers the maximum amount possible. Additionally, market actors, especially solar panels and system suppliers, are experiencing an absence of support in marketing and promoting rural energy technologies. Thus, improving access to finance should be a top priority to strengthen network electrification. Factors that affect a PV system's performance are irradiation, shading, sorting, array orientation, array asymmetry angle, array angle, roof structure and condition, the balance of system locations, latitude. During the rapid change in atmospheric climate, the cold, rainy summers from June to August and the hot, dry winters from December to February are divided into autumn (September-November) and spring (March-May). Thus, this study mainly attempts to look at the practice of alternative energy dissipation. In this way, it's possible to optimize the energy supply's orientation effects to induce the most energy from the systems. 
Solar insulation data are given in Figure 4. The clearance index is low from mid-June to mid-September, thanks to those months' rainy and cloudy days. The expected annual solar insulation is $6.23 \mathrm{kWh} / \mathrm{m}^{2}$ per day. From (Figure 4 ) shown below Solar Radiation input: Monthly Averaged radiation ( $\mathrm{kW} / \mathrm{m}^{2} /$ day).

\subsection{Impact of PV-based electrification and its social benefits}

A community-based specializes in PV-based rural electrification, and its social benefits were conducted through community elders, students, and women. Additionally, critical informative interviews and observations were made about these four-specific training kebeles $[14,31]$. The results show that almost all of the main target group participants were satisfied with the system because they'd charge their mobile phones, watch TV, worship, and lightly clean the electricity; we saw that many were surprised by the electricity. They were satisfied that their lifestyle is becoming modern and grounded within the system as their major problems are reduced, especially their disease caused by traditional lighting using oil. They also replied that, unlike a kerosene lamp, it provides high-quality light. Electricity from solar PV is also beneficial in terms of safety because it avoids the fireplace hazard caused by kerosene lamps [27]. The interview results also showed that the solar PV's electricity-based electrification solved many problems within the network altogether four villages and altered the agricultural population. It's also said that a current lighting system increases the residents' working hours and can use electrical appliances like CFL or LED lamps with higher brightness and help the scholars check and do their homework at the hours of darkness. This creates access to an academic program that will improve their lifestyle. The supply of a rural PV system increases children's learning opportunities, increases household well-being through better care of kids and the home, and increases income opportunities. In households and enterprises, there's improved communication (mobile phone) and access to information (audio-visual) [7]. During the sector survey, the shadow effect could are avoided if the installer had known about the shadow effect. Like the MoWIE Field Report, data collected from other sources show that the PV orientation problem is familiar to any other site. Specifically, these systems have hurt modulus energy efficiency.

The system size installed all told training areas; the result shows that two sorts of systems are established: $40 \mathrm{Wp}$ and $130 \mathrm{Wp}$ systems. The $40 \mathrm{Wp}$ system is meant for 1 * 7W LED power, 3 * $2 \mathrm{~W}$ dc LED light, 1 * $15 \mathrm{~W}$ hair clipper or black and white TV, small tape or radio, and mobile charging, but all told five families. Serves just for lighting and mobile charging. Although the system can power TV or radio, end users are forced to use the system just for lighting and mobile charging thanks to low economic capacity. The opposite system type observed in field visits to fifteen households was the $130 \mathrm{Wp} \mathrm{AC/DC}$ type system. This technique has power 2 * 7W LED, 3 * 2W, 3 * 1W dc LED lamp, ribbon and radio, mobile charge, 12 "or 14" TV (low power AC / DC TV, mainly utilized in the bus) long-distance passenger), DC operates on a refrigerator (with low power consumption, commonly mentioned as a solar refrigerator). Accordingly, the device installed in 15 families could be a $3 * 1 \mathrm{w}$ dc LED light bulb, mobile charge, and a 14" flat-screen TV. As for the support, the structures were traditional trees that aren't even spoiled and inspected by an expert structural engineer; the molding of local houses was random and irregular in shape, making installation very difficult, especially in household systems. The auxiliary structures used weren't strong; all told four kebeles other problems observed during the location visit, whether system components like cabinet and PV panel were unclean and covered for an extended time with dust particles. PV modules are very reliable; however, they will collect grime and mud over time in contaminated environments. Photovoltaic cells have already got low conversion efficiency; the accumulation of sand and dirt particles from the external environment further reduces the generated output energy [19]. This is often caused by a discount within the incidence of sunlight on the photovoltaic cell. Uncertain and polluted sky by dust particles can reduce the sun's incoming rays before reaching the solar cells and facilitate the work of the scheme to scale back the effect that photovoltaic panels must be protected, especially in areas susceptible to low rainfall and deserts. Therefore, creating user awareness about how dust particles can reduce sunlight and system performance should be a compulsory daily activity for end users.

\subsection{PV Orientation Analysis and Best Orientation Evaluation}

The PVsyst software was accustomed to support further and evaluates the orientation findings regarding solar orientation. The orientation of the PV system within the areas of Bahir-Dar was analyzed in keeping with the software. 
Table 1. NASA Surface Meteorology and Solar Energy: RETScreen Data Ethiopia, Latitude 8, Longitude 38 and Altitude 2324 m.

\begin{tabular}{|c|c|c|c|c|c|c|c|c|}
\hline Month & $\begin{array}{l}\text { Air } \\
\text { temperature } \\
\left({ }^{\circ} \mathrm{C}\right) \\
\end{array}$ & $\begin{array}{l}\text { Relative } \\
\text { humidity } \\
(\%)\end{array}$ & $\begin{array}{l}\text { Daily solar } \\
\text { radiation } \\
\text { horizontal } \\
\left(\mathrm{kWh} / \mathrm{m}^{2} / \mathrm{d}\right)\end{array}$ & $\begin{array}{l}\text { Atmospheric pressure } \\
(\mathrm{kPa})\end{array}$ & $\begin{array}{l}\text { Wind } \\
\text { speed } \\
(\mathrm{m} / \mathrm{s})\end{array}$ & $\begin{array}{l}\text { Earth } \\
\text { temperature } \\
\left({ }^{\circ} \mathrm{C}\right)\end{array}$ & $\begin{array}{l}\text { Heating degree } \\
\text { days } \\
\left({ }^{\circ} \mathrm{C}-\mathrm{d}\right)\end{array}$ & $\begin{array}{l}\text { Cooling degree } \\
\text { days } \\
\left({ }^{\circ} \mathrm{C}-\mathrm{d}\right)\end{array}$ \\
\hline January & 18.0 & $42.0 \%$ & 5.97 & 79.4 & 3.5 & 22.4 & 18 & 241 \\
\hline February & 19.4 & $37.7 \%$ & 6.38 & 79.3 & 3.2 & 24.4 & 3 & 257 \\
\hline March & 20.5 & $41.9 \%$ & 6.26 & 79.3 & 3.0 & 25.6 & 1 & 315 \\
\hline April & 19.8 & $54.8 \%$ & 6.12 & 79.2 & 3.1 & 24.1 & 5 & 288 \\
\hline May & 18.6 & $65.5 \%$ & 6.05 & 79.3 & 2.9 & 21.8 & 8 & 266 \\
\hline June & 16.9 & $76.8 \%$ & 5.41 & 79.4 & 3.0 & 18.6 & 29 & 213 \\
\hline July & 15.8 & $79.5 \%$ & 4.75 & 79.4 & 2.6 & 16.9 & 59 & 187 \\
\hline August & 15.8 & $79.5 \%$ & 4.87 & 79.4 & 2.3 & 16.8 & 54 & 192 \\
\hline September & 16.1 & $76.1 \%$ & 5.54 & 79.4 & 2.3 & 17.3 & 41 & 197 \\
\hline October & 16.3 & $63.0 \%$ & 6.17 & 79.4 & 2.8 & 17.8 & 49 & 197 \\
\hline November & 16.9 & $48.4 \%$ & 6.20 & 79.4 & 3.2 & 19.3 & 38 & 202 \\
\hline December & 17.2 & $46.0 \%$ & 6.02 & 79.4 & 3.4 & 20.5 & 33 & 215 \\
\hline \multicolumn{9}{|l|}{ Annual } \\
\hline $\begin{array}{l}\text { Average } \\
\text { measured }\end{array}$ & 17.6 & $42.0 \%$ & 5.97 & 79.4 & 3.5 & 22.4 & 18 & 241 \\
\hline
\end{tabular}

Document generated on Thu Apr 7 03:36:56 EDT 2016 from www.RETScreen.com

NASA data show that the sun's rays are low in June-September (Table 1). The rationale is that it's the season, and also the sunshine time is a smaller amount than average. In Ethiopia, the sun's angle and the vertical line when the sun is on the tropical Capricorn (south) are more extensive than when the sun is on common cancer (north). If we consider only the sun's position, the worth of the sun's rays on the land of Ethiopia on Dec 21 (tropical Capricorn) should be but the value of the radiation on Jun 21 (common cancer). In contrast, with actual observations and surveys of local residences, Ethiopia's season runs from June to September. The time of year is from September to March, with longer sunny seasons during this season. Thus, this information obtained from NASA will be compared with the program's results, actual observations, and local people's surveys. Accordingly, the irradiation results obtained in Bahir-Dar are analyzed about NASA and native residents' statements and presented.

\subsection{Results of Bahir Dar orientation}

The PVsyst program is employed to stimulate optimal orientation. The simulation behavior of a solar PV system depends on the angle of the lean of the PV system, the rise of the azimuth, and

Therefore the environmental condition of the positioning, like radiation [11]. The meteorological site selected for this analysis is Bahir Dar in Ethiopia, as most solar PV systems are installed during this region. The results of the Bahir-Dar optimization shown in Figure 5 of the simulation results described that in the orientation of this technique, the PV system could collect a mean of $5.36 \mathrm{kWh} / \mathrm{m}^{2}$ per day, implies that 1929.6

$\mathrm{kWh} / \mathrm{m}^{2} /$ year. This amount of energy can even be converted into a usable sort of electricity, betting on the conversion efficiency's property nature. 
$\mathrm{PV}_{\text {syst }}$ Orientation Simulation Result around Bahir Dar from (Figure 5). In addition to the inadequacy of the distribution amount, there are other problems for successful dissemination [24]. These are:

- A project-based approach to distribution, involving one-off, large-scale tender procurement as an endless critical supply of solar lighting products;

- It is impossible to convince local banks to borrow PV solar products. As a result, insufficient capital and funding wasn't available for local private companies to retort to large tenders (due to their limited involvement);

- There isn't any established market link between importers and rural distributors and installers, leaving consumers with the matter of spare parts maintenance and availability;

- Limited efforts to market the advantages of solar PV systems and, therefore, the lack of local component manufacturers have made the system's price very high.

- Lack of regulatory and legal framework supported national standards, rural awareness campaign.

- Consequently, small amounts of solar PV are distributed throughout the country, leaving most agricultural households without electricity, making them keen on fuel-covered lighting, including fossil and solid biomass fuels. This may contribute to gas emissions, air, and outdoor pollution, and native environmental degradation and influences in-house companies to not compete with them as they're characterized by low resources.

- The purchased equipment is shipped to the regions for installation performed by one company under a contract with the national $[14,31]$.

This created significant problems in an interview with end-users of the four study periods; it was reported that users have difficulty finding technicians; replacement components (e.g., a liability controller) may cause significant features, like batteries, because of replacement duration.

Other problems observed during this study are associated with the shortage of national standards for PV orientation installation. The examination shows that the installation orientation doesn't contain specific guidelines, as evidenced by the observed tilt angles [38]. Supported this study, it had been found that the performance and reliability of independent PV electrical systems were influenced by various factors like component failure, system configuration, maximum power tracking, system orientation, electrical device tracking, and environmental conditions then on [23]. Moreover, the loss of PV systems was observed everywhere, within the sample areas, because of dust accumulation, lack of system design, extreme temperature, and shading. Thus, it's crucial to adapt the quality design practice of mathematical formulation, experimental and PVsyst methods to numerical simulation to see ways to boost the performance and reliability of individual PV power systems for further practicality within the country. It's also been observed that the general public has different views about technology. Users with functional systems express positive views about technology [26]. Conversely, in cases where some components failed, users showed a negative attitude towards technology. SHS is perfect, environmentally friendly, and sustainable thanks to secure such scattered rural villages. The practice of distributing PV and installing and maintaining it within the instance faces many challenges [8].

\section{Conclusion}

As a rustic which will become a middle-income country within the next ten years, Ethiopia's electricity demand and consumption will increase significantly. More industry, commercial buildings, and residential apartments will must be inbuilt the near future, which needs high electricity. This text discusses the prevalence of solar PV around Bahir Dar. Additionally, distributed solar home systems have improved the socio-economic activities and quality of lifetime of off-grid people. Solar energy is among the cleanest, accessed with low prices and abundant sources of energy with a minimum ecological and environmental hazard.

If the orientation is established, it's assumed that the inclination angle is $15^{0}$ in all parts of the country except Bahir-Dar. Around Bahir- Dar, which is $16^{\circ}$ angles and its azimuth angle is $0^{0}$ (towards the north). For its part, Ethiopia may be a country 
rich not only in large rivers but also in high levels of sunlight, the majority year-round. The simulation of this scenario gave an annual energy yield of $1929.6 \mathrm{kWh} / \mathrm{m}^{2}$. For its part, the economic assessment showed that photovoltaic technology's energy value isn't competitive with the retail price of Ethiopian electricity. Currently, Ethiopia's standard electricity tariff is $\$ 0.03 / \mathrm{kWh}$, which is way not up to the energy cost system for the scenarios as estimated by the PVsyst program. This shows that a significant amount of energy may be generated even from a tiny low array field area if the PV arrays are at an optimal orientation. Finally, optimally designed energy quantity, a significant amount of energy, and financial savings are achieved.

Based on the study results, the subsequent recommendations are given to introduce a national regulatory and legislative framework for rural solar PV technology and stimulate the popularization of the agricultural population. Strengthening and comparative advantage of enterprises involved within the supply of solar PV technologies to rural communities is gained through an area PV module assembly. Policies that support the networking of PV systems facilitate the utilization of the proposed tariff and create tax incentives. The govt should subsidize such investments within the energy sector and the source of revenue from the carbon trade.

- Future work will specialize in hardware implementation to demonstrate that the solar can optimize the ability of the PV panel in real-environment experiments and is capable of adapting to varied installation locations and PV device configuration.

- Provision of coaching on maintenance to local end-users. This may be a sustainable solution where the technicians are available within the system to be distributed.

- The panel orientation also should be at $16^{0}$ tilt angles to the north to urge the optimum irradiance around Bahir Dar, which is for any system type.

- Further study on the carbon saving and sequestration by solar PV electrification is often a source of income by carbon trading and can make such projects more sustainable.

\section{Declarations}

\section{Authors' contributions}

The author has conducted all research activities such as data acquisition, analysis, evaluation, and results. The author read and approved the final manuscript.

Conflict of interest: The authors stated that there was no competitive interest within the authors and publication of a given research paper.

\section{Acknowledgment}

Based on this paper, The researcher wish to thank the Ministry of Irrigation, Water and Energy (MoIWE). The researcher want to acknowledge Almighty God and congratulations to Mary for seeing all of my academic pursuits and, therefore, the successful completion of this work.

\section{References}

1. Anteneh, S. (2007). Alternative energy Assessment in Ethiopia: Modelling and Measurement (Doctoral dissertation, MSc thesis).

2. Asmare, A. M., Demessie, B. A., \& Murthy, G. S. (2013). Theoretical Estimation of Algal Biomass Potential and Lipid Productivity for Biofuel Production in Ethiopia. International Journal of Science and Research, 2(6), 2319-7064.

3. Asress, M. B., Simonovic, A., Komarov, D., \& Stupar, S. (2013). Wind energy resource development in Ethiopia as an alternate energy future beyond the dominant hydropower. Renewable and Sustainable Energy Reviews, 23, 366-378.

4. Barua, D. C., Urmee, T. P., Kumar, S., \& Bhattacharya, S. C. (2001). A photovoltaic solar home system dissemination model. Progress in Photovoltaics: Research and Applications, 9(4), 313-322. 
5. Bhutto, A. W., Bazmi, A. A., \& Zahedi, G. (2011). Greener energy: Issues and challenges for Pakistan-Biomass energy prospective. Renewable and Sustainable Energy Reviews, 15(6), 3207-3219.

6. Branker, K., Pathak, M. J. M., \& Pearce, J. M. (2011). A review of solar photovoltaic Levelized cost of electricity. Renewable and sustainable energy reviews, 15(9), 4470-4482.

7. Cabraal, R. A., Barnes, D. F., \& Agarwal, S. G. (2005). Productive uses of energy for rural development. Annu. Rev. Environ. Resour., 30, 117-144.

8. Chaurey, A., \& Kandpal, T. C. (2010). Assessment and evaluation of PV-based decentralized rural electrification: an outline. Renewable and Sustainable Energy Reviews, 14(8), 2266-2278.

9. Chow, T. T. (2010). A review of photovoltaic/thermal hybrid solar technology. Applied Energy, 87(2), 365-379.

10. Deichmann, U., Meisner, C., Murray, S., \& Wheeler, D. (2011). The economics of renewable energy expansion in rural Black Africa. Energy Policy, 39(1), 215-227.

11. Dupraz, C., Marrou, H., Talbot, G., Dufour, L., Nogier, A., \& Ferard, Y. (2011). Combining solar photovoltaic panels and food crops for optimizing land use: towards new agrivoltaic schemes. Renewable energy, 36(10), 2725-2732.

12. Ellabban, O., Abu-Rub, H., \& Blaabjerg, F. (2014). Renewable energy resources: current status, prospects, and technology with their capabilities. Renewable and Sustainable Energy Reviews, 39, 748-764.

13. Fodhil, F., Hamidat, A., \& Nadjemi, O. (2019). Potential, optimization, and sensitivity analysis of photovoltaic-diesel-battery hybrid energy system for rural electrification in Algeria. Energy, 169, 613-624.

14. George, Adwek, Shen Boxiong, Moses Arowo, Paul Ndolo, and John Shimmon. (2019) "Review of solar energy development in Kenya: Opportunities and challenges." Renewable Energy Focus 29, pp. 123-140

15. Gustafsson, K., Henning, A., \& Niwong, S. (1991). Small scale utilization of renewable sources of energy: Reports from three conferences. Högskolan Dalarna.

16. Gustavsson, M. (2007). Educational benefits from solar technology-Access to solar electric services and changes in children's study routines, experiences from eastern province Zambia. Energy Policy, 35(2), 1292-1299.

17. Hossain, M., \& Islam, A. (2019). A survey on Grid Solar Roof Top System in Bangladesh (Doctoral dissertation, Daffodil International University).

18. Islam, M. S., Khan, A. M. H. R., Nasreen, S., Rabbi, F., \& Islam, M. R. (2011). Renewable energy: the key to achieving sustainable development of rural Bangladesh. Journal of Chemical Engineering, 26, 9-15.3

19. Kaldellis, J. K., \& Fragos, P. (2011). Ash deposition impacts the energy performance of photovoltaic generators. Journal of cleaner production, 19(4), 311-317

20. Kebede, K. Y. (2015). Viability study of the grid-connected solar PV system in Ethiopia. Sustainable Energy Technologies and Assessments, 10, 63-70

21. Keriri, I. K. (2013). Factors influencing adoption of solar technology in Laikipia North constituency, Kenya (Doctoral dissertation, University of Nairobi).

22. Ketlogetswe, C., \& Mothudi, T. H. (2009). Solar home systems in Botswana-Opportunities and constraints. Renewable and Sustainable Energy Reviews, 13(6-7), 1675-1678.

23. King, D. L., Boyson, W. E., \& Kratochvil, J. A. (2002, May). Analysis of things influencing the annual energy production of photovoltaic systems. In Conference Record of the Twenty-Ninth IEEE Photovoltaic Specialists Conference, 2002. (pp. 1356-1361). IEEE.

24. Knott, J., \& Wildavsky, A. (1980). If dissemination is that the solution, what's the problem? Knowledge, 1(4), 537-578.

25. Lorenzo, E. (2011). Energy collected and delivered by PV modules. Handbook of photovoltaic science and engineering, Chapitre, 22, 984-1042.

26. Mapira, J., \& Munthali, A. (2011). Household energy demand: wood fuel consumption and peri-urban deforestation within the city of Masvingo (Zimbabwe). Journal of Sustainable Development in Africa, 13(5), 269-279. 
27. Miller, D., \& Hope, C. (2000). Learning to lend for off-grid solar power: policy lessons from UN agency loans to India, Indonesia, and state. Energy Policy, 28(2), 87-105.

28. Netsanet, S. (2011). A Technical Study on Assessment of Resource Potential and Technological Options of solar power and Photovoltaic Systems for Amhara Region, Ethiopia (Doctoral dissertation, Arba Minch University).

29. Nieuwenhout, F. D. J., Van Dijk, A., Lasschuit, P. E., Van Roekel, G., Van Dijk, V. A. P., Hirsch, D., ... \& Wade, H. (2001). Experience with solar home systems in developing countries: a review. Progress in Photovoltaics: Research and Applications, 9(6), 455-474.

30. Nieuwenhout, F. D. J., Van Dijk, A., Van Dijk, V. A. P., Hirsch, D., Lasschuit, P. E., Van Roekel, G., ... \& Wade, H. (2000). Monitoring and evaluation of solar home systems. Amsterdam: Netherlands Energy Research Foundation ECN.

31. Njoh, Ambe J., Simon Etta, ljang B. Ngyah-Etchutambe, Lucy ED Enomah, Hans T. Tabrey, and Uwem Essia. (2019) "Opportunities and challenges to rural renewable energy projects in Africa: Lessons from the Esaghem Village, Cameroon solar electrification project." Renewable Energy 131, pp. 1013-1021.

32. ÖZTÜRK, A., ALKAN, S., HASIRCI, U., \& TOSUN, S. (2016). Experimental performance comparison of a 2-axis sun tracking system with a set system under the atmospheric condition of Düzce, Turkey. Turkish Journal of engineering science \& Computer Sciences, 24(5), 4383-4390.

33. Paul, D., \& Uhomoibhi, J. (2014). EDUCATION, CULTURE, AND TECHNOLOGY FOR DEVELOPMENT AND SUSTAINABILITY IN AFRICA: problems with SOLAR ELECTRICITY GENERATION AND IMPACT OF ICT IMPLEMENTATION. In Republic of South Africa INTERNATIONAL CONFERENCE ON EDUCATION (p.1).

34. Pode, R. (2013). Financing LED solar home systems in developing countries. Renewable and Sustainable Energy Reviews, 25, 596-629.

35. Ravishankar, N., Gubbins, P., Cooley, R. J., Leach-Kemon, K., Michaud, C. M., Jamison, D. T., \& Murray, C. J. (2009). Financing of worldwide health: tracking development assistance for health from 1990 to 2007. The Lancet, 373(9681), 2113-2124.

36. Rodrigues, E. M. G., Godina, R., Santos, S. F., Bizuayehu, A. W., Contreras, J., \& Catalão, J. P. S. (2014). Energy storage systems are supporting increased penetration of renewables in islanded systems. Energy, 75, 265-280.

37. Sick, F., \& Erge, T. (Eds.). (1996). Photovoltaics in buildings: a design handbook for architects and engineers. Earthscan.

38. Sulaiman, S. A., Hussain, H. H., Leh, N. S. H. N., \& Razali, M. S. (2011). Effects of Dust on the Performance of PV Panels. World Academy of Science, Engineering and Technology, 58(2011), 588-593.

39. Tessema, Z., Mainali, B., \& Silveira, S. (2014). Mainstreaming and sector-wide approaches to sustainable energy access in Ethiopia. Energy Strategy Reviews, 2(3-4), 313-322.

40. Wolde-Ghiorgis, W. (2002). Renewable energy for rural development in Ethiopia: the case for brand new energy policies and institutional reform. Energy Policy, 30(11-12), 1095-1105.

\section{Figures}




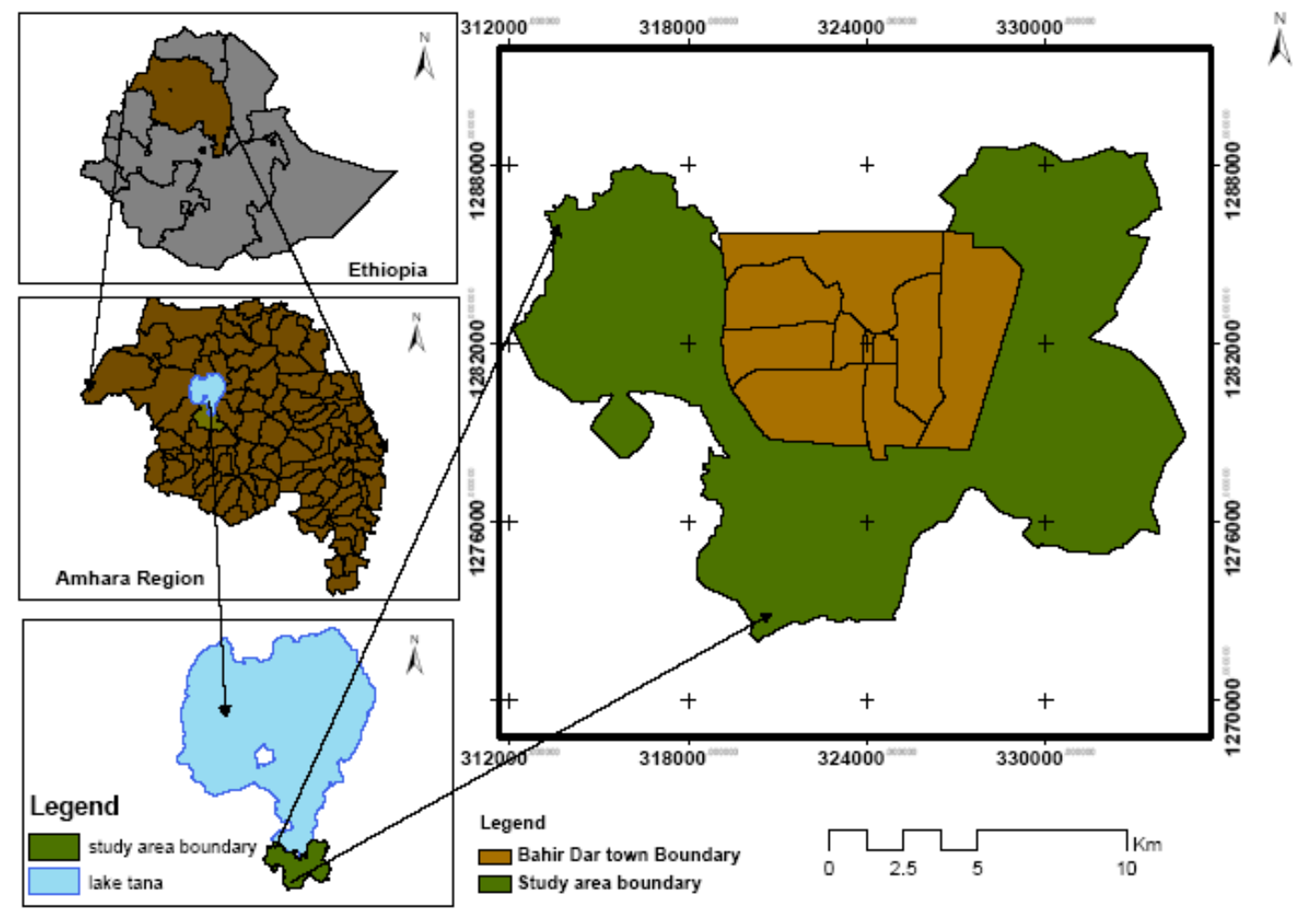

Projection:Adindan_UTM_Zoen_37N

Transverse_Mercator

Linear Unit: Meter

Figure 1

Location map of the study area

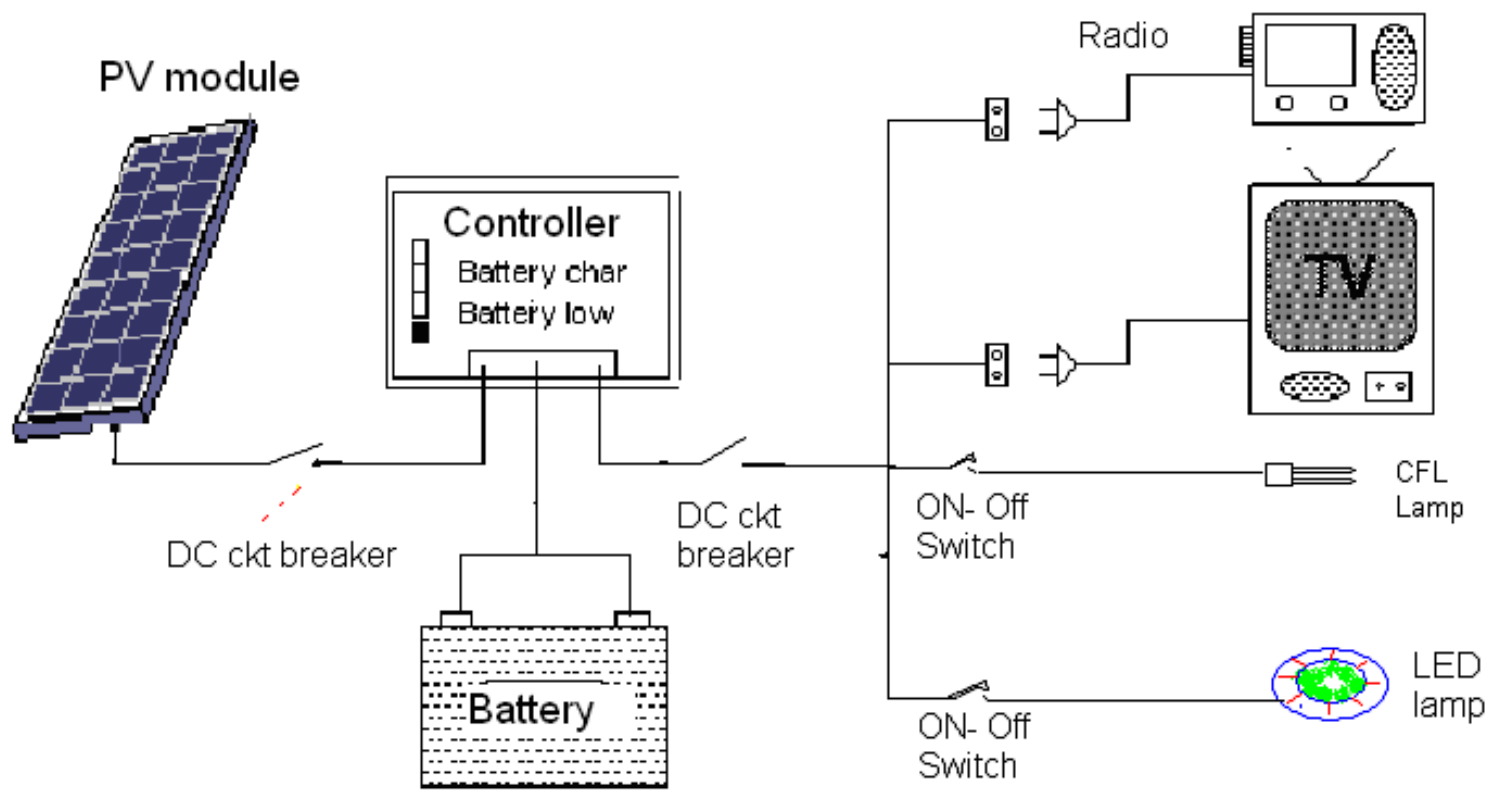

Figure 2

Circuit diagram of the DC system type 


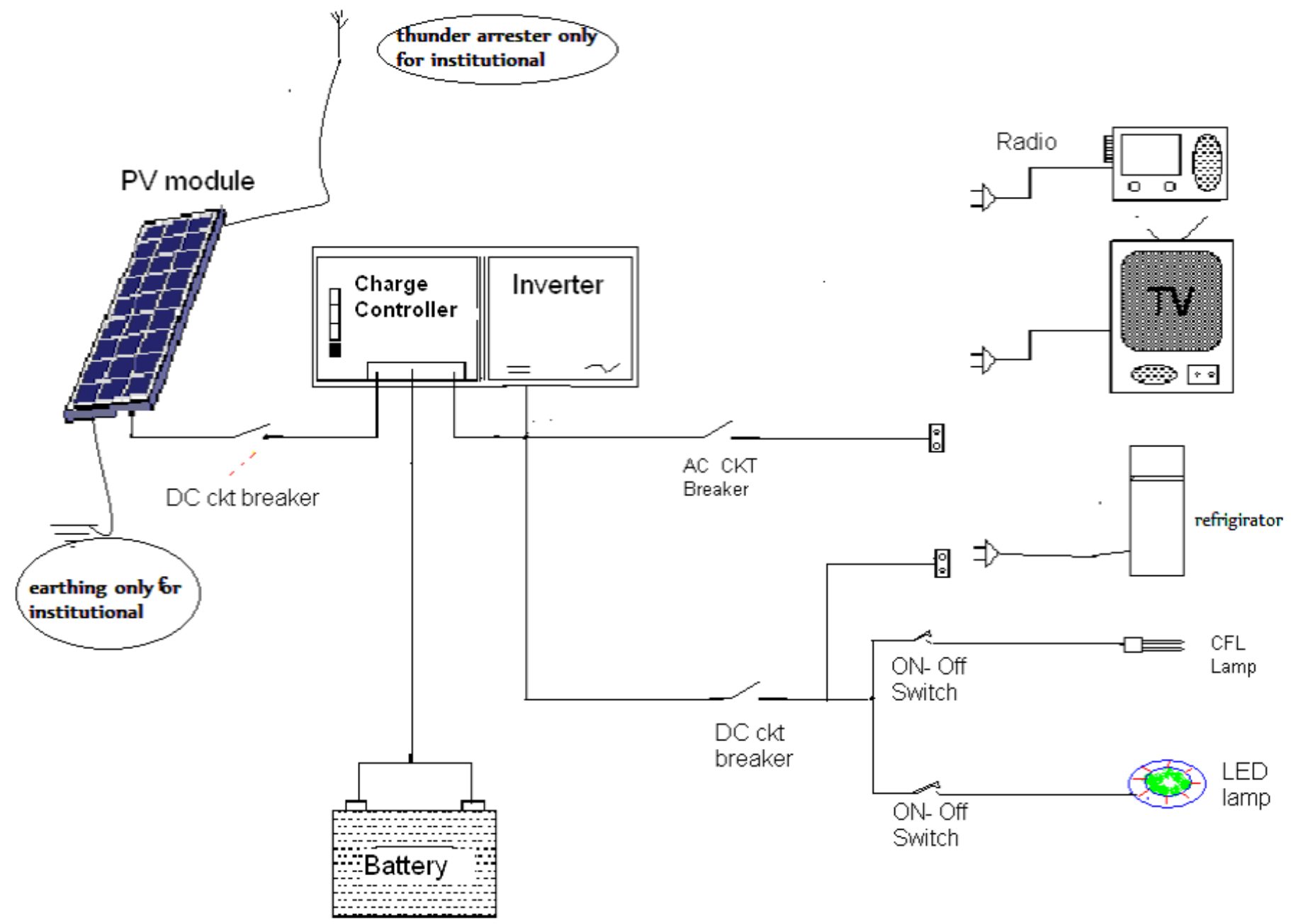

Figure 3

Circuit diagram of AC system type

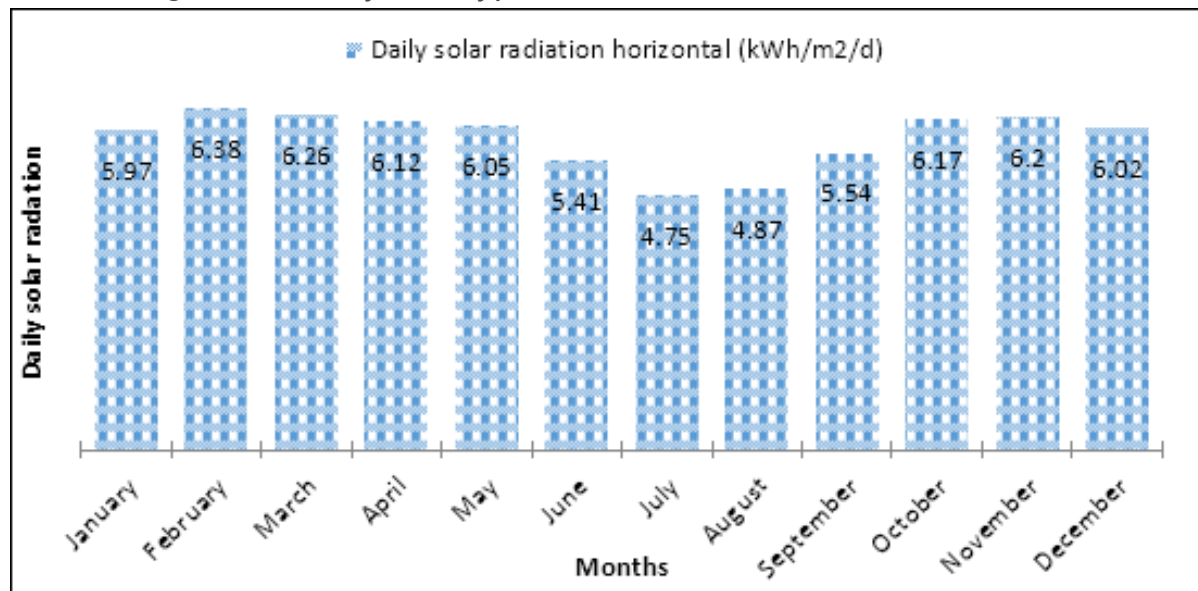

Figure 4

Solar Radiation input: Monthly Averaged radiation (kW/m2/day) 


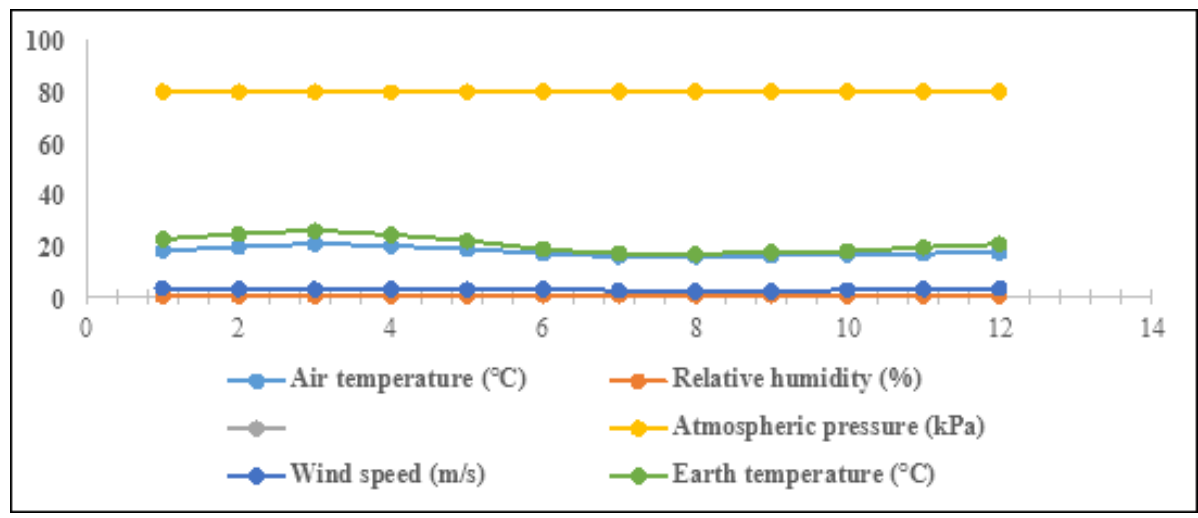

\section{Figure 5}

Graph of wind speed, relative humidity, atmospheric pressure, earth, and atmospheric air

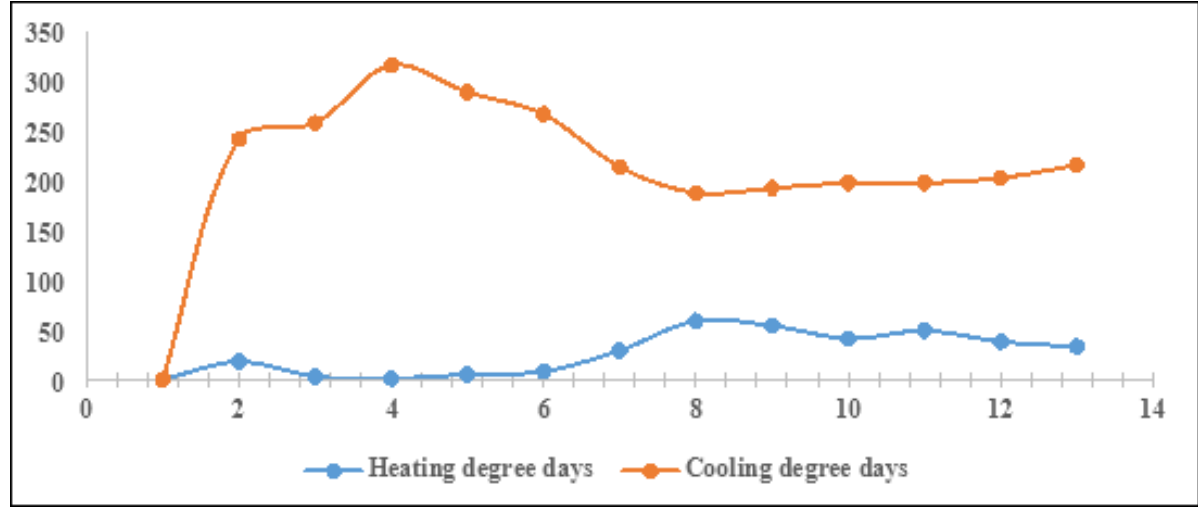

\section{Figure 6}

Heating and colling in degree celsius - days

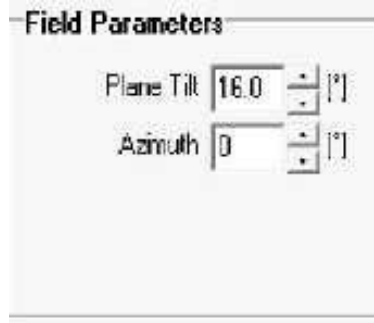

Tilt $16^{\circ}$

Azimuth $0^{\circ}$
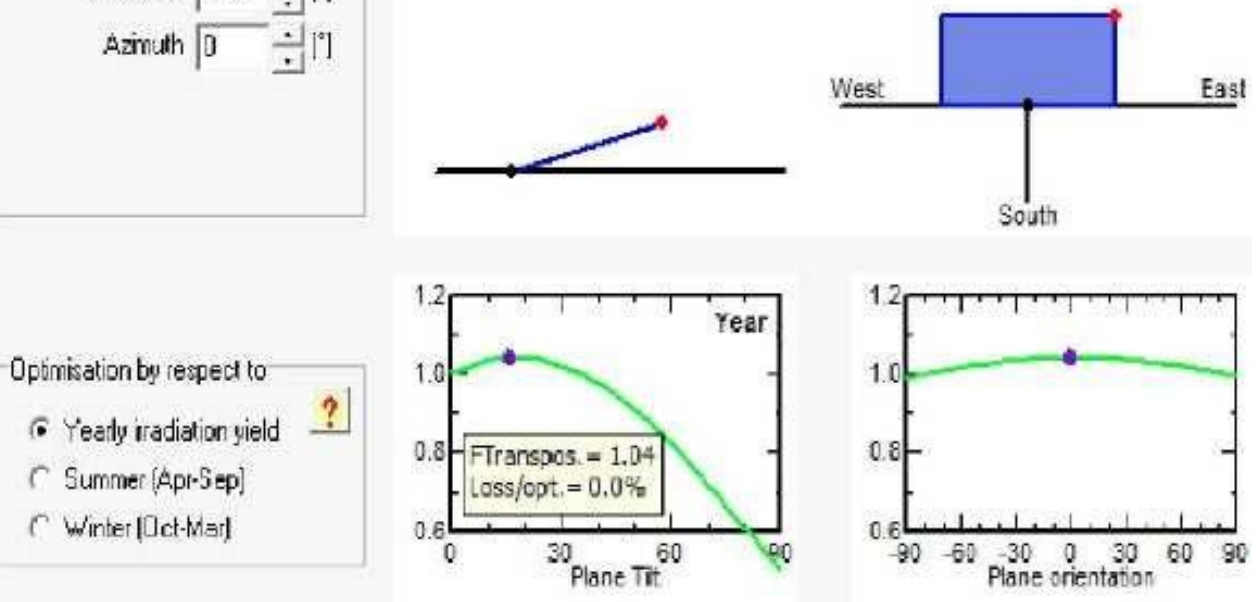

\section{Figure 7}

PVsyst Orientation Simulation Result around Bahir Dar 